THE INFLUENCE OF CORPORATE GOVERNANCE, INVESTMENT OPPORTUNITY SET, COMPANY SIZE AND IMPLEMENTATION OF PSAK 55 ON ACCOUNTING CONSERVATISM

\title{
PENGARUH CORPORATE GOVERNANCE, INVESTMENT OPPORTUNITY SET, UKURAN PERUSAHAAN, DAN PENERAPAN PSAK 55 TERHADAP KONSERVATISME AKUNTANSI
}

\author{
Lutviana Nur Hakiki, Badingatus Solikhah \\ Jurusan Akuntansi, Fakultas Ekonomi, Universitas Negeri Semarang \\ Kampus Sekaran Gunungpati Semarang \\ email: lutviananurhakiki7@gmail.com
}

\begin{abstract}
The purpose of the study is to determine and analyze the influence of managerial ownership, institutional ownership, the proportion of independent commissioners, investment opportunity set, company size and the implementation of PSAK 55 on accounting conservatism. This research based on quantitative methods using panel data regression. The population of this research is banking companies listed on the Indonesia Stock Exchange (IDX) in 2015-2017 periods. The data analysis tool used is the Eviews 9 program. The results of the study show that company size had a positive and significant effect on accounting conservatism. Meanwhile, managerial ownership, institutional ownership, the proportion of independent commissioners, investment opportunity set, and the implementation of PSAK 55 have no effect on accounting conservatism
\end{abstract}

Keywords: Corporate Governance; Investment Opportunity Set; Company Size; PSAK 55; Accounting Conservatism

\section{ABSTRAK}

Tujuan penelitian ini adalah untuk mengetahui dan menganalisis pengaruh kepemilikan manajerial, kepemilikan institusional, proporsi dewan komisaris independen, investment opportunity set, ukuran perusahaan, dan penerapan PSAK 55 terhadap konservatisme akuntansi. Penelitian ini didasarkan pada metode kuantitatif dengan menggunakan analisis regresi data panel. Populasi dalam penelitian ini adalah perusahaan perbankan yang terdaftar di Bursa Efek Indonesia (BEI) pada tahun 2015-2017. Alat analisis data yang digunakan yaitu program Eviews 9. Hasil penelitian menunjukkan bahwa ukuran perusahaan berpengaruh positif dan signifikan terhadap konservatisme akuntansi. Kepemilikan manajerial, kepemilikan institusional, proporsi dewan komisaris independen, investment opportunity set, dan penerapan PSAK 55 tidak berpengaruh terhadap konservatisme akuntansi.

Kata Kunci: Corporate Governance; Investment Opportunity Set; Ukuran Perusahaan; PSAK 55; Konservatisme Akuntansi 


\section{PENDAHULUAN}

Kualitas laporan keuangan menjadi salah satu aspek penting yang saat ini menjadi sorotan berbagai pihak di dunia pasar modal. Menurut Salehi dan Sehat (2018) informasi keuangan yang berkualitas mengarahkan pada keputusan keuangan yang lebih baik dari calon investor dan memberikan kontribusi yang lebih tepat pada alokasi sumber keuangan mereka. Laporan keuangan dijadikan sebagai tolak ukur penilaian dan evaluasi terhadap kinerja manajemen pada periode waktu tertentu. Sehingga dijadikan sebagai pertanggungjawaban dari pihak manajemen atas kinerjanya dalam mengelola berbagai sumber daya yang dimiliki oleh sebuah perusahaan.

Standar akuntansi keuangan memberikan kebebasan (flexibility principle) pada perusahaan dalam memilih metode dan estimasi akuntansi yang digunakan untuk menyajikan laporan keuangan yang dianggap sesuai dengan kondisi perusahaan (Sulastri \& Anna, 2018). Kebebasan tersebut menunjukkan bahwa perusahaan dapat memilih salah satu alternatif dalam Standar Akuntansi Keuangan yang berlaku. Perusahaan bebas melaporkan keuangannya baik secara optimis maupun konservatif.

Laporan keuangan harus memiliki tujuan agar bisa dikatakan relevan (relevance) dan dapat merepresentasikan secara tepat apa yang direpresentasi (faithful representation). Seperti yang dimaksud dalam PSAK tujuan laporan keuangan adalah untuk memberikan informasi mengenai posisi keuangan, kinerja keuangan, dan arus kas entitas yang bermanfaat bagi sebagian besar pengguna laporan keuangan dalam pembuatan keputusan ekonomik. Untuk mengakui transaksi atau peristiwa tertentu dalam laporan keuangan harus mengandung beberapa kriteria, seperti definisi, keterukuran, relevansi, dan reliabilitas. Laporan keuangan merupakan sumber informasi utama bagi investor, sehingga Bursa Efek Indonesia (BEI) mewajibkan semua perusahaan yang listing untuk mengungkapkan laporan keuangannya. Keberadaan laporan keuangan memberikan kepercayaan investor terhadap pasar dan kinerja perusahaan. Perusahaan yang listing di bursa cenderung dituntut untuk menyajikan informasi keuangan yang memiliki kredibilitas tinggi, karena dianggap dapat mencerminkan kondisi keuangan perusahaan yang sehat. Berdasarkan Kerangka Konseptual Pelaporan Keuangan (KKPK) yang disahkan oleh Ikatan Akuntansi Indonesia, informasi keuangan dapat dikatakan berkualitas apabila informasi tersebut terbanding (comparable), terverifikasi (verifiable), tepat waktu (timely), dan terpaham (understandable). Hal ini mendorong manajemen untuk melakukan berbagai upaya agar laporan keuangan dapat terlihat sebaik mungkin sehingga dapat meningkatkan nilai perusahaan sekaligus untuk menghindari penilaian buruk terkait kinerja manajemen.

Di Indonesia masih banyak dijumpai perusahaan yang terindikasi melakukan manipulasi laporan keuangan, artinya masih terdapat perusahaan yang belum sepenuhnya menerapkan konsep konservatisme akuntansi. Contoh kasus manipulasi laporan keuangan dilakukan oleh perusahaan perbankan yaitu PT Bank Bukopin, Tbk. Dikutip dari Detik Finance yang diterbitkan pada 27 April 2018, perusahan melakukan manipulasi data kartu kredit yang menyebabkan posisi kredit dan pendapatan berbasis komisi Bank Bukopin meningkat tajam. Kasus tersebut menyebabkan perusahaan harus melakukan restated (penyampaian kembali) laporan keuangannya untuk tahun 2015, 2016, dan 2017. 
Hasil dari resated tersebut menunjukkan adanya penurunan laba bersih pada tahun 2016 menjadi Rp 183,56 miliar dari sebelumnya Rp 108 triliun.

Adanya kasus manipulasi laporan keuangan dapat menyebabkan turunnya kepercayaan stakeholder terhadap laporan keuangan perusahaan. Hal ini mendorong perusahaan untuk menerapkan prinsip-prinsip konservatisme. Prinsip konservatisme ini merupakan prinsip dasar yang selalu berpengaruh terhadap praktik akuntansi dan pelaporan keuangan (Zeghal \& Lahmar, 2018). FASB mendefinisikan konservatisme akuntansi sebagai reaksi bijaksana terhadap ketidakpastian untuk mencoba memastikan bahwa ketidakpastian dan risiko yang melekat pada suatu bisnis dipertimbangkan secara memadai. Menurut Arabloo (2017) sejumlah penelitian menyarankan penggunaan konservatisme pada kondisi normal, hal ini dikarenakan kepentingan pendekatan konservatis lebih besar dibandingkan dengan biaya yang dikeluarkan. Penggunaan prinsip konservatisme menunjukkan bahwa manajemen harus berhati-hati dalam dalam menyajikan laporan keuangan. Konservatisme dapat mengurangi perilaku oportunistik manajer, sehingga dapat meningkatkan kualitas informasi keuangan (Yunos, Ahmad, \& Sulaiman, 2014)

Penelitian ini bertujuan untuk menguji secara empirik pengaruh dari kepemilikan manajerial, kepemilikan institusional, proporsi dewan komisaris independen, investment opportunity set, ukuran perusahaan, dan penerapan PSAK 55 terhadap konservatisme akuntansi. Orisinalitas dalam penelitian ini yaitu digunakannya penerapan PSAK 55 yang erat kaitannya dengan instrumen keuangan perbankan sebagai variabel baru yang diduga dapat mempengaruhi penerapan konservatisme akuntansi dalam perusahaan perbankan.

Landasan teori yang digunakan dalam penelitian ini yaitu teori agensi dan teori akuntansi positif. Jensen dan Meckling (1976) menjelaskan bahwa teori agensi terkait dengan hubungan keagenan sebagai kontrak antara dua pihak yaitu prinsipal dan agen untuk melakukan beberapa kegiatan atas nama prinsipal dalam kapasitasnya sebagai pengambil keputusan. Al-Sraheen et al. (2014) berpendapat bahwa masalah keagenan muncul karena adanya pertentangan kepentingan diantara pemegang saham dan manajemen perusahaan. Teori keagenan dalam penelitian ini digunakan untuk menjelaskan penerapan konservatisme akuntansi yang dilihat dari laporan keuangan perusahaan untuk mengatasi masalah keagenan.

Teori akuntansi positif didasarkan pada ketidakpuasan terhadap teori normatif, dimana teori akuntansi positif ini lebih berorientasi kepada penelitian yang bersifat empirik. Ghozali dan Chariri (2014) menjelaskan bahwa teori akuntansi positif menggunakan asumsi bahwa manajemen diberikan kebebasan untuk memilih metode akuntansi. Kebebasan tersebut berpotensi menimbulkan kecenderungan bagi manajer untuk memilih metode akuntansi yang hanya menguntungkan kepentingan pribadi. Penerapan prinsip konservatisme akuntansi menjadi solusi terbaik untuk mencegah perilaku oportunistik manajer dalam pengakuan laba. Menurut Pashaki dan Kheradyar (2015) pelaporan keuangan yang konservatis dapat meningkatkan efisiensi informasi akuntansi dengan mengurangi optimisme manajemen dalam memprediksikan laba.

Masalah keagenan dapat dicerminkan dalam berbagai bentuk, misalnya adanya indikasi kecurangan dalam pelaporan keuangan. Sehingga, untuk mengatasi konsekuensi yang timbul akibat konflik keagenan tersebut, diperlukan adanya tata kelola perusahaan atau corporate governance yang baik (Farizal et al. 
2017; Nasr \& Ntim, 2018). Indikator corporate governance yang digunakan dalam penelitian ini adalah kepemilikan manajerial, kepemilikan institusional, dan proporsi dewan komisaris independen. Berdasarkan teori agensi, kepemilikan saham oleh pihak manajerial dapat memperkecil konflik keagenan antara manajer dengan pemilik atau pemegang saham. Agustian dan Yuliandhari (2014) menjelaskan bahwa dengan manajer ikut memiliki saham perusahaan maka manajer tidak mungkin bertindak opportunistic, manajer akan lebih berhati-hati dan berusaha untuk meminimumkan biaya keagenan sehingga bisa meningkatkan nilai perusahaan. Kepemilikan saham oleh manajerial akan mendorong manajemen untuk lebih memperhatikan kualitas laba, mengingat akan berdampak pada keuntungan dari saham yang dimiliki. Jadi, semakin tinggi kepemilikan manajerial maka manajemen akan berusaha lebih giat dalam meningkatkan nilai perusahaan demi kepentingan pemegang saham. Selain itu, pengungkapan laba juga akan dilakukan secara hati-hati salah satunya dengan menggunakan metode akuntansi yang konservatif.

\section{H1: Kepemilikan manajerial berpengaruh positif terhadap konservatisme akuntansi}

Teori keagenan menyatakan bahwa kepemilikan institusional memiliki peran penting dalam mengurangi masalah keagenan antara pihak manajemen (agen) dengan stakeholder (prinsipal). Hal ini sejalan dengan pendapat Risdiyani dan Kusmuriyanto (2015) yang menyatakan bahwa kepemilikan saham oleh institusional dapat meningkatkan peran dalam melakukan pengawasan terhadap kinerja manajemen dalam mengelola perusahaan. Sehinga semakin besar kepemilikan saham institusional maka akan semakin besar pengaruhnya dalam mengawasi kinerja manajemen. Upaya untuk menghindari adanya manajemen laba yang berlebihan, kepemilikan saham institusional yang tinggi mendorong permintaan penggunaan akuntansi yang lebih konservatif dalam pelaporan keuangan.

\section{H2: Kepemilikan institusional berpengaruh positif terhadap konservatisme akuntansi.}

Teori agensi menyatakan bahwa adanya dewan komisaris independen dapat mengurangi permasalaham moral hazard antara pemegang saham dan manajer dengan melakukan pengawasan terhadap kinerja manajemen serta untuk melindungi kepentingan pemilik dan pemegang saham. Dalam menjalankan tugasnya dewan komisaris independen ini tidak berpihak pada kepentingan manapun, sehingga dapat melakukan pengawasan terhadap kinerja manajemen dengan lebih profesional. Menurut Mulya (2014) semakin banyak proporsi dewan komisaris independen, maka tingkat pengawasan manajer akan semakin ketat dan penerapan konservatisme juga semakin tinggi, karena adanya persyaratan informasi keuangan yang berkualitas. Sehingga dengan diterapkannya prinsip konservatisme akuntansi dapat membantu upaya dewan komisaris untuk mengurangi agency cost dan meningkatkan kualitas informasi keuangan dari perusahaan.

\section{H3: Proporsi dewan komisaris independen berpengaruh positif terhadap konservatisme akuntansi}

Investment opportunity set (IOS) mencerminkan biaya yang dikeluarkan oleh manajemen untuk memperoleh return yang lebih besar di masa depan. Luasnya return tersebut sangat bergantung pada besarnya expenditure yang dikorbankan oleh perusahaan (Aristantia \& Putra, 2015). Sehingga besarnya IOS dapat dilihat 
dari nilai capital expenditure to book value asset (CAPBVA) yang membandingkan pengukuran investasi dalam bentuk aktiva tetap. Berdasarkan teori agensi, IOS dapat mengurangi konflik keagenan diantara manajer dengan pemegang saham melalui keputusan investasi yang diambil oleh manajemen. Murwaningsari dan Rachmawati (2017) menyatakan bahwa peluang investasi dapat memberikan reaksi positif terhadap harga saham, yang berarti market to book value sebagai proksi konservatisme juga semakin tinggi dan nantinya berdampak pada peningkatan nilai perusahaan. Jadi semakin besar nilai IOS maka market to book ratio juga semakin besar, dengan demikian nilai konservatisme akuntansi yang diterapkan oleh perusahaan juga akan meningkat.

\section{H4: Investment opportunity set berpengaruh positif terhadap konservatisme akuntansi}

Ukuran perusahaan merupakan salah satu indikator yang digunakan untuk melihat besarnya biaya politik yang harus ditanggung oleh perusahaan. Berdasarkan teori akuntansi positif, perusahaan besar cenderung memiliki biaya politis yang lebih tinggi, sehingga perusahaan akan berupaya untuk memperkecil laba yang ditampilkan pada laporan keuangan. Hal ini dilakukan manajer karena semakin besar perusahaan maka kewajiban perpajakannya juga semakin meningkat. Dilihat dari adanya hipotesis political cost, dapat disimpulkan bahwa semakin besar ukuran suatu perusahaan, maka akan semakin menarik perhatian pemerintah terkait dengan pengenaan tarif pajak. Situasi ini akan mendorong diterapkannya prinsip akuntansi yang lebih konservatif dengan melaporkan laba cenderung lebih rendah, sehingga dapat menghindarkan perusahaan dari pembayaran pajak yang terlalu tinggi.

\section{H5: Ukuran perusahaan berpengaruh positif terhadap konservatisme akuntansi}

Berdasarkan agensi teori, asimetri informasi yang terjadi diantara pihak agen dan prinsipal dapat dikurangi dengan adanya informasi keuangan yang berkualitas. Laporan keuangan dapat dikatakan berkualitas apabila sesuai dengan standar yang berlaku, salah satunya dengan berpedoman terhadap Standar Akuntansi Keuangan (SAK). PSAK 55 tentang pengakuan dan pengukuran instrumen keuangan membahas mengenai penurunan nilai dan tidak tertagihnya aset keuangan. PSAK 55 merupakan peraturan yang dianggap paling kompleks dalam dunia perbankan. Peraturan dalam PSAK 55 akan mempersempit kemungkinan adanya kecurangan yang dilakukan perusahaan, karena aset maupun liabilitas keuangan dicatat secara hati-hati menggunakan nilai wajar yang paling relevan dengan aktivitas perusahaan sehingga manajer akan memilih akuntansi yang bersifat konservatif.

\section{H6: Penerapan PSAK 55 berpengaruh positif terhadap konservatisme akuntansi}

\section{METODE PENELITIAN}

\subsection{Populasi, Sampel dan Teknik Pengambilan Sampel}

Populasi dalam penelitian ini adalah perusahaan perbankan yang terdaftar pada Bursa Efek Indonesia (BEI) periode 2015-2017 yang berjumlah 41 perusahaan. Metode dalam pengambilan data sampel adalah sampel jenuh yang merupakan teknik penentuan sampel dengan menjadikan seluruh anggota populasi sebagai sampel. 


\subsection{Variabel Penelitian}

Tabel 1. Operasioal Variabel Penelitian

\begin{tabular}{cc}
\hline No & Variabel \\
\hline 1 & $\begin{array}{c}\text { Konservatisme } \\
\text { akuntansi }\end{array}$
\end{tabular}

mempercepat pengakuan biaya dan memperlambat pengakuan pendapatan, serta mengakui aset pada nilai terendah, dan beban pada nilai tertinggi.

Kepemilikan
Manajerial

Persentase jumlah saham yang dimiliki manajer terhadap jumlah saham yang beredar

\section{Pengukuran}

\author{
MTB \\ Clossing price \\ $\overline{\text { Equity per share }}$
}

(Beaver \& Ryan, 2000) $\sum$ saham yang dimiliki direksi $\frac{\text { dan komisaris }}{\sum \text { saham yang beredar }} \times 100 \%$

(Hertina \& Zulaikha, 2017)

\begin{tabular}{|c|c|c|c|}
\hline 3 & $\begin{array}{l}\text { Kepemilikan } \\
\text { Institusional }\end{array}$ & $\begin{array}{l}\text { Persentase jumlah } \\
\text { saham yang dimiliki } \\
\text { institusional (institusi } \\
\text { keuangan) terhadap } \\
\text { jumlah saham yang } \\
\text { beredar }\end{array}$ & 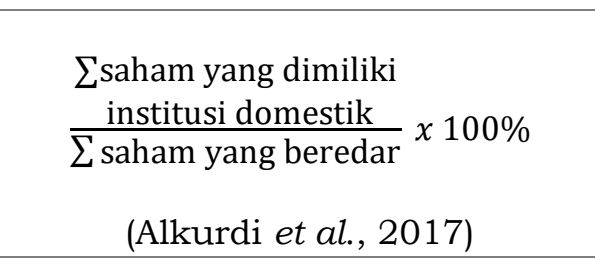 \\
\hline 4 & $\begin{array}{l}\text { Proporsi Dewan } \\
\text { Komisaris } \\
\text { Independen }\end{array}$ & $\begin{array}{c}\text { Komposisi dewan } \\
\text { komisaris independen } \\
\text { terhadap seluruh jumlah } \\
\text { dewan komisaris }\end{array}$ & $\begin{array}{l}\frac{\sum \text { komisaris independen }}{\sum \text { anggota dewan komisaris }} \times 100 \% \\
\text { (Risdiyani \& Kusmuriyanto, 2015) }\end{array}$ \\
\hline 5 & $\begin{array}{c}\text { Investment } \\
\text { Opportunity Set }\end{array}$ & $\begin{array}{l}\text { Pilihan investasi yang } \\
\text { tersedia bagi perusahaan } \\
\text { untuk memperoleh } \\
\text { manfaat dimasa depan }\end{array}$ & $\begin{array}{c}\text { CAPBVA } \\
\frac{\text { Ni. Buku AT } \mathrm{t}-\mathrm{Ni} \text {. Buku AT } \mathrm{t}-\mathrm{i}}{\text { Total aset }} \\
\text { (Andreas, Ardeni, \& Nugroho, } \\
\text { 2017) }\end{array}$ \\
\hline 6 & $\begin{array}{c}\text { Ukuran } \\
\text { Perusahaan }\end{array}$ & $\begin{array}{l}\text { Besar kecilnya kekayaan } \\
\text { (aset) yang dimiliki } \\
\text { perusahaan }\end{array}$ & $\begin{array}{c}\text { Ln (total aset) } \\
\text { (Susanto \& Ramadhani, 2016) }\end{array}$ \\
\hline 7 & $\begin{array}{l}\text { Penerapan } \\
\text { PSAK 55 }\end{array}$ & $\begin{array}{c}\text { PSAK } 55 \text { adalah } \\
\text { pernyataan standar } \\
\text { akuntansi keuangan } \\
\text { yang ditetapkan oleh } \\
\text { Ikatan Akuntansi } \\
\text { Indonesia mengenai } \\
\text { instrument keuangan: } \\
\text { pengakuan dan } \\
\text { pengukuran }\end{array}$ & $\begin{array}{c}\text { PSAK 55 } \\
\frac{\text { CKPN Individu + CKPN Kolektif }}{\text { Aset Produktif }} \times 100 \% \\
\text { (Laporan Keuangan) }\end{array}$ \\
\hline
\end{tabular}

Sumber: data sekunder yang diolah tahun 2019 . 


\subsection{Teknik Pengumpulan Data dan Teknik Analisis Data}

Penelitian ini menggunakan data sekunder yang dikumpulkan menggunakan teknik dokumenter. Data yang diambil berupa laporan tahunan (annual report) perusahaan perbankan yang terdaftar di Bursa Efek Indonesia pada periode 2015-2017. Metode analisis yang digunakan dalam penelitian ini adalah analisis statistik deskriptif dan regresi data panel menggunakan Eviews 9. Pengujian yang dilakukan harus terlebih dahulu lolos dari uji asumsi klasik.

\section{HASIL DAN PEMBAHASAN}

\subsection{Analisis Statistik Deskriptif}

Pengujian ini bertujuan untuk memberikan gambaran mengenai suatu data dengan melihat dari nilai rata-rata (mean), standar deviasi, varian maksimum dan minimum dari masing-masing variabel penelitian yaitu konservatisme akuntansi, kepemilikan manajerial, kepemilikan institusional, proporsi dewan komisaris independen, investment opportunity set, ukuran perusahaan dan peneran PSAK 55.

Tabel 2. Hasil Uji Statistik Deskriptif

\begin{tabular}{|c|c|c|c|c|}
\hline \multirow{2}{*}{ Variabel } & \multicolumn{4}{|c|}{ Statistik Deskriptif } \\
\hline & Mean & Minimum & Maksimum & $\begin{array}{c}\text { Std. } \\
\text { Deviasi }\end{array}$ \\
\hline \multicolumn{5}{|c|}{$\mathrm{n}=120$} \\
\hline \multicolumn{5}{|l|}{ Variabel Dependen } \\
\hline Konservatisme Akuntansi & 1,485943 & 0,018300 & 4,667400 & 0.985054 \\
\hline \multicolumn{5}{|l|}{ Variabel Independen } \\
\hline Kepemilikan Manajerial & 0,029171 & 0,000000 & 0,720700 & 0.115699 \\
\hline Kepemilikan Institusional & 0,205033 & 0,000000 & 0,894400 & 0.259527 \\
\hline $\begin{array}{l}\text { Proporsi Dewan Komisaris } \\
\text { Independen }\end{array}$ & 0.573785 & 0,000000 & 1,00000 & 0.121887 \\
\hline Investment Opportunity Set & 0,026914 & $-0,224200$ & 2,127800 & 54.17807 \\
\hline Ukuran Perusahaan & 30,77431 & 22,748900 & 34,74150 & 2.325325 \\
\hline Penerapan PSAK 55 & $1,61 \%$ & $0.03 \%$ & $9,6 \%$ & 1.522747 \\
\hline
\end{tabular}

Sumber: data sekunder yang diolah tahun 2019

Hasil uji deskriptif pada tabel 2 menunjukkan bahwa variabel konservatisme akuntansi mempunyai nilai tertinggi sebesar 4,6674 yang dimiliki oleh PT Bank Ina Perdana, Tbk (BINA) pada tahun 2017. Sedangkan nilai terendah sebesar 0,0183 yang dimiliki oleh PT Bank Panin Syariah, Tbk (PNBS) pada tahun 2017. Nilai rata-rata lebih besar dari standar deviasi menunjukkan bahwa sebaran data untuk variabel konservatisme akuntansi menyebar secara heterogen.

Tabel 3. Hasil Uji Multikolinearitas

\begin{tabular}{lllllll}
\hline & KM & KI & DKI & IOS & SIZE & PSAK \\
\hline KM & 1.000000 & -0.1485 & 0.104111 & -0.02956 & -0.19042 & -0.20204 \\
\hline KI & -0.1485 & 1.000000 & -0.1223 & 0.008647 & -0.06322 & -0.1734 \\
\hline DKI & 0.104111 & -0.1223 & 1.000000 & -0.00692 & -0.06644 & -0.13607 \\
\hline IOS & -0.02956 & 0.008647 & -0.00692 & 1.000000 & -0.15831 & 0.027350 \\
\hline
\end{tabular}




\begin{tabular}{lllllll}
\hline SIZE & -0.19042 & -0.06322 & -0.06644 & -0.15831 & 1.000000 & 0.238766 \\
\hline PSAK & -0.20204 & -0.1734 & -0.13607 & 0.027350 & 0.238766 & 1.000000
\end{tabular}

Sumber: data sekunder yang diolah tahun 2019

Uji asumsi klasik dalam penelitian ini terdiri dari uji multikolinearitas yang dan uji heterokedastisitas. Hasil uji multikolinearitas dapat dilihat pada tabel 3 yang menunjukkan bahwa nilai tolerance dari seluruh variabel independen masih dibawah 0,8. Dengan demikian dapat disumpulkan bahwa dapat penelitian ini model regresi data panel terbebas dari masalah multikolinearitas, sehingga dapat dilakukan tahapan uji asumsi klasiknya berikutnya.

Tabel 4. Hasil Uji Heterokedastisitas

Heteroskedasticity Test: Breusch-Pagan-Godfrey

$\begin{array}{cccc}\text { F-statistic } & 1.090629 & \text { Prob. F(6,113) } & 0.3724 \\ \text { Obs* }{ }^{*} \text {-squared } & 6.568750 & \text { Prob. Chi-Square(6) } & 0.3626 \\ \text { Scaled explained SS } & 9.244605 & \text { Prob. Chi-Square(6) } & 0.1603\end{array}$

Sumber: data sekunder yang diolah tahun 2019

Hasil uji heterokedastisitas yang menggunakan uji Breusch-Pagan-Godfrey dapat dilihat pada tabel 4 yang menunjukkan bahwa variabel independen tidak memiliki pengaruh terhadap regresi logaritma residual kuadrat model regresi data panel karena memiliki prob. Chi-square sebesar 0.3626 , artinya seluruh variabel independen memiliki nilai $p$ value lebih besar dari 0,05. Sehingga, model regresi data panel yang digunakan dalam penelitian ini terbebas dari adanya masalah heterokedastisitas.

\subsection{Hasil Pengujian Hipotesis}

Tabel 5. Koefisien Determinasi Model Regresi Data Panel

\begin{tabular}{lrll}
\hline R-squared & 0.818962 & Mean dependent var & 1.485943 \\
Adjusted R-squared & 0.708872 & S.D. dependent var & 0.985054 \\
S.E. of regression & 0.531499 & Akaike info criterion & 1.857009 \\
Sum squared resid & 20.90435 & Schwarz criterion & 2.925548 \\
Log likelihood & -65.42056 & Hannan-Quinn criter. & 2.290948 \\
F-statistic & 7.438985 & Durbin-Watson stat & 2.579874 \\
Prob(F-statistic) & 0.000000 & & \\
\hline
\end{tabular}

Sumber: data sekunder yang diolah tahun 2019 
Model regresi data panel dalam penelitian ini memiliki nilai adjusted $\mathrm{R}^{2}$ sebesar 0,708872. Hal ini menujukkan bahwa kepemilikan manajerial, kepemilikan institusional, proporsi dewan komisaris independen, investment opportunity set, ukuran perusahaan dan penerapan PSAK 55 dapat menerangkan konservatisme akuntansi sebesar 70,9\%, sedangkan sisanya sebesar 29,1\% dijelaskan oleh variabel lain diluar model regresi data panel dalam penelitian ini. Hasil uji simultan (uji statistik f) menunjukkan nilai probabilitas untuk F-statistik adalah 0,0000 dan lebih kecil dari 5\%, maka kepemilikan manajerial, kepemilikan institusional, proporsi dewan komisaris independen, investment opportunity set, ukuran perusahaan dan penerapan PSAK 55 secara simultan atau bersama-sama mempengaruhi konservatisme akuntansi secara signifikan. Hasil parameter individual (uji t) dapat dilihat pada tabel 6

Tabel 6. Hasil Uji t

\begin{tabular}{|c|c|c|c|c|c|}
\hline Variabel & $\begin{array}{l}\text { Prediksi } \\
\text { Tanda }\end{array}$ & Koefisien & t-statistik & $\begin{array}{c}\text { Prob. } \\
(a=5 \%)\end{array}$ & Hasil \\
\hline $\begin{array}{l}\text { Kepemilikan } \\
\text { Manajerial }\end{array}$ & - & $-0,453530$ & $-0,159294$ & 0,8739 & Ditolak \\
\hline $\begin{array}{l}\text { Kepemilikan } \\
\text { Institusional }\end{array}$ & - & $-1,518,614$ & $-1,885308$ & 0,0633 & Ditolak \\
\hline $\begin{array}{l}\text { Proporsi Dewan } \\
\text { Komisaris Indpenden }\end{array}$ & + & 0,533985 & 0,845328 & 0,4007 & Ditolak \\
\hline $\begin{array}{l}\text { Investment } \\
\text { Opportunity Set }\end{array}$ & - & $-0,011399$ & $-0,034724$ & 0,9724 & Ditolak \\
\hline Ukuran Perusahaan & + & $1,783,895$ & $4,146,903$ & 0,0001 & Diterima \\
\hline Penerapan PSAK 55 & + & 0,022595 & $-4,024405$ & 0,6792 & Ditolak \\
\hline
\end{tabular}

Sumber: data sekunder yang diolah tahun 2019

\subsection{Pembahasan}

Hipotesis pertama dalam penelitian ini ditolak, karena secara empiris kepemilikan manajerial tidak memiliki pengaruh terhadap konservatisme akuntansi. Tidak adanya pengaruh kepemilikan manajerial terhadap konservatisme akuntansi disebabkan karena adanya usaha perusahaan mencatatkan laba yang tinggi untuk mendapat pengakuan dari pihak luar. Perusahaan dengan laba yang besar akan lebih mudah untuk mencari pendanaan, karena dapat meyakinkan kreditur dalam memberikan pinjaman serta menarik minat investor untuk berinvestasi di perusahaan tersebut. Pada umumnya manajer bekerja sesuai dengan bonus yang akan diterima. Hal ini didorong oleh target suatu perusahaan yang cenderung berorietasi pada laba. Faktor lain yang kemungkinan menyebabkan kepemilikan manajerial tidak berpengaruh terhadap konservtisme akuntansi yaitu jumlah kepemilikan saham manajerial pada sektor perbankan yang menjadi sampel dalam penelitian ini masih cukup rendah. Bahkan terdapat beberapa perusahaan perbankan yang sahamnya tidak dimiliki oleh pihak manajerial. Hasil penelitian ini bertolak belakang dengan Risdiyani dan Kusmuriyanto (2015) serta Suleiman (2014) yang menyatakan bahwa dengan adanya kepemilikan saham oleh pihak manajerial akan mendorong perusahaan untuk meningkatkan kualitas pelaporan keuangan dengan penerapan konservatisme akuntansi yang lebih tinggi. 
Hipotesis kedua dalam penelitian ini ditolak, karena secara empiris kepemilikan institusional tidak memiliki pengaruh terhadap konservatisme akuntansi. Tidak berpengaruhnya kepemilikan institusional terhadap konservatisme akuntansi disebabkan karena adanya kepemilikan dengan jumlah yang masih tergolong rendah, sehingga pihak institusional merasa tidak memiliki perusahaan dan hanya fokus pada keamanan investasi mereka serta return yang akan didapatkan. Kepemilikan institusional pada perusahaan perbankan yang terdaftar di BEI masih sangat rendah, hal ini dicerminkan pada analisis statistik deskriptif yang menujukkan nilai rata-rata kepemilikan institusional sebesar 0,205033. Rendahnya kepemilikan institusional mengindikasikan bahwa aktivitas monitoring terhadap kinerja manajemen belum berjalan secara optimal. Hasil penelitian ini bertolak belakang dengan hasil temuan Al-Sraheen et al. (2014) serta Alkurdi et al. (2017) yang menemukan adanya pegaruh positif antara kepemilikan institusional terhadap konservatisme akuntansi.

Hipotesis ketiga dalam penelitian ini ditolak, karena secara empiris proporsi dewan komisaris independen tidak berpengaruh terhadap konservatisme akuntansi. Keberadaan dewan komisaris independen terbukti tidak berpengaruh terhadap konservatisme akuntansi. Hal tersebut disebabkan karena pengangkatan dewan komisaris independen kemungkinan tidak untuk menegakkan good corporate governance, namun hanya untuk memenuhi ketentuan formal. Tidak berpengaruhnya proporsi dewan komisaris independen terhadap konservatisme akuntansi, didasarkan bahwa komisaris independen merupakan pihak yang berasal dari luar perusahaan, yang memungkinkan mereka memiliki keterbatasan informasi sehingga tidak memahami secara baik mengenai kondisi perusahaan. Penunjukkan pihak eksternal sebagai dewan komisaris independen tersebut tidak dilakukan secara tepat, namun hanya untuk memenuhi regulasi. Hasil temuan dalam penelitian ini bertolak belakang dengan hasil penelitian Risdiyani dan Kusmuriyanto (2015) dan Indrasari et al. (2017) yang beranggapan bahwa dengan adanya komisaris independen maka kinerja manajemen akan terkontrol dengan baik, sehingga dapat meningkatkan kualitas informasi dalam laporan keuangan dengan menerapkan akuntansi yang lebih konservatis.

Hipotesis keempat dalam penelitian ini ditolak, karena secara empiris investment opportunity set tidak berpengaruh terhadap konservatisme akuntansi. Tidak berpengaruhnya investment opportunity set terhadap konservatisme akuntansi disebabkan karena perusahaan belum memaksimalkan pilihan kesempatan investasi yang dimiliki. Pada perusahaan perbankan yang menjadi sampel dalam penelitian ini menujukkan masih terdapat beberapa bank yang memiliki nilai investment opportunity cost minus, seperti yang terjadi pada Bank Nusantara Parahyangan, Tbk (BBNP), Bank Danamon Indoensia, Tbk (BDMN), Bank Pembangunan Daerah Banten, Tbk (BEKS) serta beberapa bank lainnya. Hal ini mengindikasikan bahwa perusahaan tersebut memiliki pertumbuhan investasi yang rendah. Hasil analisis deskripitif menujukkan bahwa rata-rata perusahaan sampel memiliki nilai investment opportunity set hanya sebesar 0,026914 yang artinya tergolong rendah. Hasil penelitian ini sejalan dengan hasil penelitian yang dilakukan oleh Saptono dan Gurendrawati (2014) serta Dwitayanti dan Fahlefi (2015) yang menyatakan bahwa investment opportunity set tidak berpengaruh terhadap konservatisme akuntansi. 
Hipotesis kelima dalam penelitian ini diterima, karena secara empiris ukuran perusahaan berpengaruh positif dan signifikan terhadap konservatisme akuntansi. Hasil penelitian ini sesuai dengan political cost hypothesis pada teori akuntansi positif yang beranggapan bahwa perusahaan besar cenderung memiliki biaya politis yang tinggi, sehingga mendorong perusahaan untuk mengurangi nilai present value dengan cara menunda pengakuan laba dan aktiva yang ditampilkan pada laporan keuangan agar nilainya tidak overestimate. Sehingga dapat disimpulkan bahwa perusahaan besar akan bertindak lebih hati-hati dalam melaporkan laba dan cenderung memilih untuk menerapkan akuntansi yang lebih konservatis dengan tujuan untuk menekan besarnya biaya politis yang harus ditanggung perusahaan. Hasil penelitian mendukung hasil penelitian Susanto dan Ramadhani (2016) yang menujukkan bahwa ukuran perusahaan berpengaruh positif dan signifikan terhadap konservatisme akuntansi.

Hipotesis keenam dalam penelitian ini ditolak, karena secara empiris penerapan PSAK 55 tidak berpengaruh terhadap Konservatisme Akuntansi. PSAK 55 ini memberikan batasan yang jelas bagi manajemen perusahaan dalam menyusun laporan keuangan. Sehingga PSAK 55 tidak mempengaruhi keputusan manajer dalam menerapkan konservatisme akuntansi. Dengan adanya batasan yang jelas, perusahaan tidak dapat melaporkan laba secara oversestimate maupun underestimate. Tidak berpengaruhnya penerapan PSAK 55 terhadap konservatisme akuntansi, diduga disebabkan karena perusahaan hanya menerapkan PSAK 55 secara formalitas sebagai bentuk kepatuhan terhadap standar akuntansi yang berlaku. PSAK 55 yang diadopsi dari IFRS tersebut merupakan penganutan prinsipal basis yang dianut, hal dikarenakan hanya menekankan pada prinsip dan konsep namun pengaplikasiannya tergantung pada praktik yang ada. Hal ini yang menyebabkan bank belum menerapkan PSAK 55 secara maksimal sehingga tidak memiliki dampak secara signifikan terhadap keputusan manajemen dalam menerapkan prinsip akuntansi yang konservatif.

\section{PENUTUP}

Berdasarkan analisis yang telah dilakukan, maka dapat diambil kesimpulan bahwa ukuran perusahaan berpengaruh dalam meningkatkan penerapan konservatisme akuntansi. Semakin besar ukuran perusahaan, maka manajemen akan terdorong untuk menerapkan akuntansi yang konservatif. Hal ini dilakukan untuk menekan besarnya biaya politis yang harus ditanggung perusahaan. Sementara itu, variabel kepemilikan manajerial, kepemilikan institusional, proporsi dewan komisaris independen, investment opportunity set, dan penerapn PSAK 55 tidak berpengaruh terhadap konservatisme akuntansi.

Saran bagi pihak eksternal baik calon kreditur maupun investor diharapkan lebih memperhatikan ukuran perusahaan, dikarenakan perusahaan dengan ukuran besar akan bertindak lebih konservatif, sehingga dapat meminimalisir adanya tindakan oportunistik oleh manajemen. Penelitian selanjutnya diharapkan dapat menggunakan pengukuran konservatisme selain ukuran aset bersih, misalnya berdasarkan ukuran akrual seperti yang dilakukan Givoly dan Hayn (2000) untuk melakukan perbandingan antar teknik pengukuran konservatisme agar mendapatkan hasil yang lebih komprehensif. 


\section{DAFTAR PUSTAKA}

Agustian, G. G., \& Yuliandhari, W. S. (2014). Pengaruh Kepemilikan Manajerial, Kepemilikan Institusional, dan Kebijakan Deviden Terhadap Kebijakan Utang Perusahaan. E-Proceeding of Management, 1(3).

Al-Sraheen, D. A.-D. O., Fadzil, F. H. B., \& Ismail, S. S. B. S. (2014). The Influence of Corporate Ownership Structure and Board Members' Skills on the Accounting Conservatism : Evidence from Non-Financial Listed Firms in Amman Stock Exchange. International Journal of Accounting and Financial Reporting, 4(1). https://doi.org/10.5296/ijafr.v4i1.5661

Alkurdi, A., Al-Nimer, M., \& Dabaghia, M. (2017). Accounting Conservatism and Ownership Structure Effect: Evidence from Industrial and Financial Jordanian Listed Companies. International Journal of Economics and Financial Issues, 7(January 2015), 608-619. https: / / doi.org/10.1504/IJHTM.2015.074538

Andreas, H. H., Ardeni, A., \& Nugroho, P. I. (2017). Konservatisme Akuntansi di Indonesia. Jurnal Ekonomi Dan Bisnis, 2O(1), 1. https://doi.org/10.24914/jeb.v20i1.457

Arabloo, M. D. (2017). Auditor Tenure and Accounting Conservatism : Testing Moderating Effect of Owner' s Importance. Engineering, Technology \& Applied Science Research, 7(4), 1883-1887.

Aristantia, D., \& Putra, I. M. P. D. (2015). Investment Opportunity Set dan Free Cash Flow pada Tingkat Pembayaran Deviden Perusahaan Manufaktur. EJurnal Akuntansi Universitas Udayana, 11(1), 220-234.

Dwitayanti, Y., \& Fahlefi, R. (2015). Pengaruh Kepemilikan Manajerial, Investment Opportunity Set (IOS), Price To Book Ratio, dan Political Cost Terhadap Konservatisma Akuntansi. Jurnal Akuntanika, 2(1), 31-43.

Farizal, N., Kamran, M., \& Ji, A. X.-D. (2017). Accounting Conservatism, Corpoeate Governance and Political Connections. Asian Review of Accounting, 25(2). https: / / doi.org/10.1108/ARA-04-2012-0017

Hertina, N. rizki, \& Zulaikha. (2017). Analisis Penerapan Konservatisme Akuntansi di Indonesia dalam Perspektif Positive Accounting Theory. Diponegoro Journal of Accounting, 6(3), 1-10. Retrieved from http://ejournals1.undip.ac.id/index.php/accounting

Indrasari, A., Yuliandhari, W. S., \& Triyanto, D. N. (2017). Pengaruh Komisaris Independen, Komite Audit, Dan Financial Distress Terhadap Integritas Laporan Keuangan. Jurnal Akuntansi, 2O(1), 117. https://doi.org/10.24912/ja.v20i1.79

Mulya, A. A. (2014). Pengaruh Mekanisme GCG, Audit Brand Name dan Ukuran Perusahaan Terhadap Konservatisme Akuntansi. Jurnal Akuntansi Dan Keuangan, 3(2), 168-187.

Murwaningsari, E., \& Rachmawati, S. (2017). he Influence of Capital Intensity and Investment Opportunity Set toward Conservatism with Managerial Ownership as Moderating Variable. Journal of Advanced Management Science, 5(6), 445451. https://doi.org/10.18178/joams.5.6.445-451

Nasr, M. A., \& Ntim, C. G. (2018). Corporate governance mechanisms and accounting conservatism: evidence from Egypt. Corporate Governance (Bingley), 18(3), 386-407. https://doi.org/10.1108/CG-05-2017-0108

Pashaki, M. M., \& Kheradyar, S. (2015). An Investigation into the Effect of Audit Quality on Accounting Conservatism in Companies Listed in Tehran Stock 
Exchange. International Letters of Social and Humanistic Sciences, 50, 107117. https://doi.org/10.18052/www.scipress.com/ilshs.50.107

Risdiyani, F., \& Kusmuriyanto. (2015). Analisis Faktor- faktor Yang Mempengaruhi Penerapan Konservatisme Akuntansi. Accounting Analysis Journal, 4(3), 1-10.

Salehi, M., \& Sehat, M. (2018). Debt Maturity Structure, Institutional Ownership and Accounting Conservatism Evidence from Iranian listed Companies. Asian Journal of Accounting Reserach. https://doi.org/10.1108/AJAR-05-20180001

Saptono, R., \& Gurendrawati, E. (2014). Pengaruh Kepemilikan Manajerial, Invstment Opportunity, dan Debt Covenant Terhadap Konservatisme Akuntansi. Jurnal Ilmiah Mahasiswa Akuntansi, 9(2).

Sulastri, S., \& Anna, Y. D. (2018). Pengaruh financial distress dan leverage terhadap konservatisme akuntansi. AKUISISI | Jurnal Akuntansi, Volume 14(pengungkapan), 58-68.

Suleiman, S. (2014). Coporate Governance Mechanisms and Accounting Conservatism. Journal of Management Policies and Practices, 2(2), 113-127.

Susanto, B., \& Ramadhani, T. (2016). Faktor-Faktor Yang Memengaruhi Konservatisme (Studi pada Perusahaan Manufaktur yang Terdaftar di BEI 2010-2014). Jurnal Bisnis Dan Ekonomi, 23(2), 142-151.

Yunos, R. M., Ahmad, S. A., \& Sulaiman, N. (2014). The Influence of Internal Governance Mechanisms on Accounting Conservatism. Procedia-Social and Behavioral Sciences, 164(August), 501-507. https://doi.org/10.1016/j.sbspro.2014.11.138

Zeghal, D., \& Lahmar, Z. (2018). International Journal of Accounting \& Informasi Manajemen. 